\title{
Pharmacognosy
}

\section{Editorial: Rodriguésia and Pharmacognosy - an interaction that reminds us of Barbosa Rodrigues}

This Special Issue of Rodriguésia was dedicated to the $12^{\text {th }}$ Brazilian Symposium of Pharmacognosy and the $17^{\text {th }}$ Latin American Symposium of Pharmacobotany that took place on May 7-10, 2019, at Petrópolis, Rio de Janeiro, Brazil. The events received 400 participants from all Brazilian regions as well as from other South American countries such as Argentina, Chile, Paraguay, Peru and Uruguay. The program included 37 national and international speakers who presented relevant and current topics related to Pharmacognosy and Pharmacobotany. The Brazilian Symposium of Pharmacognosy is a traditional event with national and international repercussions organized every two years by the Brazilian Society of Pharmacognosy (SBFgnosia). In 2019 the Symposium became recognized as one of the most important events dedicated to Pharmacognosy, Natural Products and Medicinal Plants in Brazil.

Pharmacognosy is one of the oldest branches of Pharmaceutical Sciences, involving multi- and interdisciplinary aspects such as the study of physical, chemical, biochemical and biological properties of drugs of natural origin and searching for new drugs of natural sources such as plants, animals, microorganisms and marine organisms. Pharmacognosy also dialogues with agricultural, ecology and public policy sciences devoted to medicinal plants and herbal medicines. In this context, the $12^{\text {th }}$ Brazilian Symposium of Pharmacognosy and the $17^{\text {th }}$ Latin American Symposium of Pharmacobotany aimed to promote the integration of researchers, professionals, scholars and students, providing the possibility of dialogue and updating, which resulted in debates and rich intellectual productions, promoting significant advances in these sciences.

In Brazil, Pharmacognosy and Pharmacobotany contribute enormously to the Brazilian Pharmacopoeia and to the study of native medicinal plants. In this context, João Barbosa Rodrigues (1842-1909), a Brazilian naturalist and director of the Rio de Janeiro Botanical Garden from 1892 to 1909, recognized and valued in his work the indigenous knowledge of the Brazilian flora in medicine, cuisine and housing, also recording the vernacular names of plants. Barbosa Rodrigues' expeditions to various regions of Brazil, including the Amazon rainforest, are valuable records of his perception about the country's environmental and socio-cultural context, representing portraits of local knowledge. His studies on orchids, palm trees - the publication of the classic book of national Botany Sertum Palmarum Brasiliensium crowned his career as a naturalist - and the use of plants by natives, such as the preparation of "curare", a poison used by indigenous people, caused him to become one of the main actors in the scenario of genuinely Brazilian Science (Peixoto et al. 2012; Marcolin 2013). In 1935 the Journal Rodriguésia was launched by the Rio de Janeiro Botanical Garden, with its title being a tribute to Barbosa Rodrigues, who in his management as director of the Institution was responsible for significant changes such as the creation of a herbarium, a museum and the reformulation of the arboretum. In its first issue, the presentation of the new journal highlights: "We do not need to increase the significance of this tribute to the great Brazilian botanist, internationally known and that with the circulation of this journal will always be remembered, inside and outside the borders of our land" (Campos Porto et al. 1935).

It is important to highlight that, as a naturalist, Barbosa Rodrigues went far beyond Botany, being active in several areas of science and enabling integration between them. Thus, in recognition of the spirit of the one who inspired the journal, Rodriguésia produced this Special Issue, expanding its scope of publications. After the conferences, the period for submission of manuscripts began. The manuscripts received went through the same regular peer review process of Rodriguésia and followed the same norms and processes. A total of 22 papers 
were accepted from several Brazilian universities (20) and also from Argentina (2), among them original papers (16), review articles (2), short communications (3) and a point of view paper (1). All five Brazilian regions were included, with papers from the North (1), Northeast (1), Midwest (2), South (2) and Southeast (14). Papers were classified into the following areas of Pharmacognosy: Chemical characterization and biological activities of natural products (8), Extraction methods and quality control of plant materials (4), Isolation and structural characterization of natural products (2), Herbal Drug Technology (1), Ethnobotany and Ethnopharmacology (2), Plant Biotechnology (1), Plant Chemosystematics (1) and Phytotherapy in Public Health (1), also including two review articles.

Review articles addressed topics such as photoprotective properties of natural products (Chiari-Andréo et al.) and ethnobotanical, ecological, pharmacological and chemical aspects of the medicinal and food plant Anredera cordifolia (Ten.) Steenis, known as "bertalha" (Alba, Pelegrin \& Sobottka). In the research papers, many authors investigated the chemical composition of plant species as well as the biological activities of the extracts, e.g. the antiviral activity of Cissus erosa Rich. (Reis et al.), the anti-hypertensive activity of Ipomoea pes-caprae (L.) R. Br. (Gonçalves et al.), the wound healing activity of Lafoensia pacari A. St.-Hil. (Chaibub et al.), the antimicrobial and antiparasitic activity of Senna rugosa (G. Don) H.S. Irwin \& Barneby (Cunha et al.), the antioxidant activity of Dalbergia ecastaphyllum (L.) Taub. (Lucas et al.), the antinociceptive activity of volatile fractions of Solidago chilensis Meyen (Valverde et al.), and the antimycobacterial, antiparasitic and cytotoxic activities of the volatile oils of Spiranthera odoratissima A. St.-Hil. (Cabral et al.). Musso et al. evaluated the apoptosis induction of non-polar extracts of Nicotiana glauca Graham in cancer cells. Extraction methods and quality control of plant raw materials were reported by Neves, Nakamura et al., who quantified triterpenes in Protium spp. oleoresins; Neves, Mello et al., with extraction of phenolic compounds of Campomanesia lineatifolia Ruiz \& Pav.; Lima et al., with optimization of an eco-friendly extraction method and detection of coumarins in Justicia pectoralis Jacq., and Rocha et al., determining the terpene profile in Cannabis L. varieties for medical purposes. Paganelli et al. evaluated quantitatively the phenolic compounds of Myrcia splendens (Sw.) DC. by HPLC-ESI-MS/MS, while Kelly, Oliveira \& Valverde determined the chemical profile of Solidago canadensis L. by UFLC-PDA-ESI-TOF. In the Ethnobotany and Ethnopharmacology area, Siqueira et al. described the medicalization of medicinal plants popularly known as "mercury" and Rodrigues \& Oliveira wrote a reflection about whether Ethnopharmacology is a laboratory Science. Guimarães et al. presented a study about the genus Maytenus Molina in the Plant Chemosystematics area. The only paper about Herbal Drug Technology described the development of a tablet formulation of Silybum marianum (L.) Gaertn. (Cianchino et al.). Lozano et al. reported about in vitro cell culture of the Amazonian species Duroia saccifera (Mart. ex Roem. \& Schult.) Hook. f. ex Schumann in the Plant Biotechnology area. Finally, Phytotherapy in Public Health was represented by Matos et al. showing the e-SUS tool for registration of the use of medicinal plants in the Jequitinhonha valley, Brazil.

The invited editors would like to thank, first of all, the editorial board of Rodriguésia, mainly the Editorin-Chief Karen L. G. De Toni, for opening their scope to the Brazilian Society of Pharmacognosy, expanding the possibilities to publish the studies on Natural Products under pharmacognostic and pharmacobotanical aspects. They also thank the authors for their scientific contributions and the reviewers for their valuable and detailed comments about the manuscripts. More than a celebration of the $12^{\text {th }}$ Brazilian Symposium of Pharmacognosy and the $17^{\text {th }}$ Latin American Symposium of Pharmacobotany, this Special Issue is a celebration of Pharmacognosy, Pharmacobotany and Science.

\author{
Leopoldo C. Baratto \\ Presidente da Sociedade Brasileira \\ de Farmacognosia \\ Universidade Federal do Rio de Janeiro \\ Rio de Janeiro - RJ - Brasil \\ ORCID: 0000-0002-7125-7431 \\ leopoldo@pharma.ufrj.br
}

\author{
Danilo R. Oliveira \\ Coordenador de Biodiversidade \\ PR2/UFRJ \\ Universidade Federal do Rio de Janeiro \\ Rio de Janeiro - RJ - Brasil \\ ORCID: 0000-0001-5697-6510 \\ oliveiradr@pharma.ufr.br
}

\author{
Juliana V. Paulino \\ Professora Adjunta \\ Universidade Federal do Rio de Janeiro \\ Rio de Janeiro - RJ - Brasil \\ ORCID: 0000-0003-0072-639X \\ jvillelapaulino@pharma.ufr.br
}

Rodriguésia 71: ed012020. 2020 


\section{References}

Campos Porto P, Silveira FR \& Penna LA (1935) Apresentação. Rodriguésia 1: 1-2.

Marcolin N (2013) A glória do botânico. Pesquisa Fapesp 210: 88-89. Available at $<$ https://revistapesquisa. fapesp.br/2013/08/13/a-gloria-do-botanico/>
Peixoto AL, Guedes-Bruni RR, Haverroth M \& Silva IM (2012) Saberes e práticas sobre plantas: a contribuição de Barbosa Rodrigues. Revista Brasileira de História da Ciência 5: 22-30. 